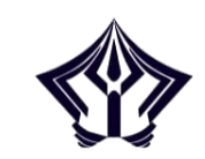

ANFUSINA: JOURNAL OF PSYCHOLOGY

http://ejournal.radenintan.ac.id/index.php/anfusina

DOI://dx.doi.org/10.24042/ajp.v2i1.4312

Volume 2, Nomor 1, April Tahun 2019

\title{
Tekanan Psikologis dan Kesejahteraan Subjektif Keluarga di Wilayah Perdesaan dan Perkotaan
}

Intan Islamia
UIN Raden Intan Lampung
intanislamia@ radenintan.ac.id
Euis Sunarti
Institut Pertanian Bogor
euissunarti@apps.ipb.ac.id
Neti Hernawati
Institut Pertanian Bogor
netihernawati@apps.ipb.ac.id

\begin{abstract}
The purpose of this research is to examine the differences of psychological stress and subjective well-being of families in rural and urban areas. This study is a subsampling research from the main research "The Variability of Family Strength in Indonesia". This research took two locations from the main research: there are Empang and Mulyaharja Regency, which involved 60 samples. Data was collected through interview with self-developed questionnaire. Results showed that more than half (60.2\%) of families in both regions experienced psychological stress in the form of worry about things. Nearly half (46.7\%) of families in rural areas and almost a quarter (23.3\%) of families in urban areas experienced low subjective well-being. Results of the independent sample t-test showed that psychological stress and subjective well-being were higher in families in urban areas.
\end{abstract}




\begin{abstract}
Abstrak
Tujuan penelitian ini adalah mengkaji perbedaan tekanan psikologis dan kesejahteraan subjektif keluarga di wilayah perdesaan dan perkotaan. Penelitian ini merupakan subsampling dari penelitian utama mengenai "Keragaan Ketahanan Keluarga Indonesia". Penelitian ini mengambil dua lokasi dari penelitian utama yakni Kelurahan Empang dan Mulyaharja dengan melibatkan 60 orang contoh. Data diperoleh melalui hasil wawancara menggunakan kuesioner yang dikembangkan oleh peneliti. Hasil penelitian menunjukkan bahwa lebih dari separuh $(60,2 \%)$ keluarga di kedua wilayah mengalami tekanan psikologis berupa hal-hal yang mengkhawatirkan. Hampir separuh $(46,7 \%)$ keluarga di wilayah perdesaan dan hampir seperempat $(23,3 \%)$ keluarga di wilayah perkotaan memiliki kesejahteraan subjektif yang rendah. Hasil uji beda independent sample t-test menunjukkan bahwa tekanan psikologis dan kesejahteraan subjektif lebih tinggi pada keluarga di wilayah perkotaan.
\end{abstract}

Keyword: psychological stress, subjective well-being, family, rural, urban

\title{
Pendahuluan
}

Perpaduan antara kondisi bangsa saat ini dan perkembangan zaman yang pesat menuntut disegerakannya perbaikan. Peningkatan kualitas manusia berhubungan dengan kualitas dari sistem sosial yang disebut keluarga (Sunarti 2011). Keluarga berperan sebagai institusi yang memberikan pengaruh paling utama dan pertama terhadap individu (Baxter et al. 1951; Bronfenbrenner 1979; Cooley 1909 dalam Reiss 1980; Berns 1985). Dalam perkembangannya, keluarga mengalami berbagai proses pengelolaan baik masalah maupun sumber daya yang ada untuk mencapai tujuan utama, yakni kesejahteraan keluarga (Sunarti 2001). Terdapat dua jenis pendekatan yang digunakan dalam mengukur kesejahteraan keluarga, yaitu pendekatan objektif dan subjektif. Kesejahteraan subjektif merupakan persepsi yang dirasakan oleh masyarakat sendiri tentang aspek kesejahteraan (Diener 1984; Iskandar 2007; Suandi 2007; Conceição \& Bandura 2008; Kusumo \& Simanjuntak 2009).

Dalam upaya mencapai kesejahteraan, keluarga juga tidak terlepas dari adanya tantangan. Salah satunya berupa tekanan, baik tekanan sosial maupun tekanan psikologis. Lingkungan dimana keluarga menetap turut mempengaruhi kondisi dan perkembangan 
keluarga (Bronfenbrenner 1979; Berns 1985). Keluarga yang tinggal di wilayah perdesaan tentu memiliki perbedaan dengan keluarga yang tinggal di perkotaan, baik dari segi karakteristik, nilai dan norma, tekanan yang dihadapi, maupun kesejahteraan subjektifnya. Terwujudnya kesejahteraan keluarga juga menjadi bagian dari upaya pembangunan SDM Indonesia yang lebih berkualitas. Oleh karena itu, penelitian ini bertujuan untuk mengkaji tekanan psikologis dan kesejahteraan subjektif keluarga di wilayah perdesaan dan perkotaan.

\section{Metode Penelitian}

Penelitian ini merupakan subsampling dari penelitian utama dengan tema "Keragaan Ketahanan Keluarga Indonesia" (Sunarti 2012). Disain yang digunakan dalam penelitian utama adalah cross sectional study, dengan melibatkan 240 contoh yang dipilih menggunakan stratified disproportional random sampling. Penelitian ini mengambil dua lokasi dari penelitian utama yakni Kelurahan Empang dan Kelurahan Mulyaharja, Kota Bogor.

Populasi dalam penelitian utama adalah seluruh keluarga dengan kriteria suami dan istri yang masih lengkap serta memiliki anak usia sekolah. Penelitian utama melibatkan 240 contoh yang dipilih menggunakan stratified disproportional random sampling, sedangkan penelitian ini mengambil sebanyak 60 contoh dari penelitian utama, yakni 30 contoh di wilayah perdesaan dan 30 contoh di wilayah perkotaan.

Data yang digunakan dalam penelitian ini merupakan data primer yang dikumpulkan melalui interview dengan menggunakan kuesioner yang dikembangkan oleh Sunarti (2012). Data meliputi karakteristik keluarga, tekanan sosial, tekanan psikologis, dan kesejahteraan subjektif. Pertanyaan untuk tekanan sosial dan tekanan psikologis merupakan pertanyaan semi terbuka yang memiliki konstruk. Konstruk dikembangkan dari penelitian mengenai Ketahanan Keluarga (Sunarti 2003). Data sekunder yang digunakan adalah data demografi Kelurahan Empang dan Kelurahan Mulyaharja, Kota Bogor.

Data yang telah diperoleh dalam penelitian ini diolah menggunakan program Microsoft Excel dan SPSS for Windows. Pengolahan data dilakukan melalui proses editing, coding, scoring, 
entry data, cleaning data, dan analyze data. Selanjutnya, data dikategorikan kemudian dianalisis secara deskriptif dan uji independent-samples t-test.

\section{Hasil dan Pembahasan}

Tekanan psikologis mengacu pada hubungan dengan lingkungan dimana seseorang menilai sendiri keadaannya dalam kondisi tuntutan yang melebihi sumber daya yang tersedia (Lazarus 1993). Hasil penelitian menunjukkan tekanan psikologis tinggi dialami oleh 6,7 persen keluarga di wilayah perkotaan, sedangkan seluruh (100\%) keluarga di perdesaan mengalami tekanan psikologis rendah.

\section{Tekanan Psikologis}

\section{Tabel 1.}

Sebaran keluarga berdasarkan jenis

\begin{tabular}{lcccc}
\hline \multicolumn{1}{c}{ Jenis tekanan } & Desa $(\%)$ & $\begin{array}{c}\text { Kota } \\
(\boldsymbol{\%})\end{array}$ & $\begin{array}{c}\text { Total } \\
(\boldsymbol{\%})\end{array}$ & p-value \\
\hline Hal-hal yang mengkhawatirkan & 31,8 & 28,4 & 60,2 & 0,000 \\
$\begin{array}{l}\text { Hal-hal yang menakutkan } \\
\text { Ketidakpastian yang membuat tidak }\end{array}$ & 6,7 & 38,5 & 45,2 & 0,001 \\
$\begin{array}{l}\text { Kenang } \\
\text { Kehilangan yang membuat sedih }\end{array}$ & 3,3 & 18,4 & 21,7 & 0,005 \\
\hline
\end{tabular}

Terdapat empat jenis tekanan psikologis yang diteliti, yakni hal-hal yang mengkhawatirkan, hal-hal yang menakutkan, ketidakpastian yang membuat tidak tenang, dan kehilangan yang membuat sedih. Lebih dari separuh $(60,2 \%)$ keluarga di kedua wilayah mengalami tekanan berupa hal-hal yang mengkhawatirkan. Kekhawatiran utama yang diungkapkan berkaitan dengan anak, keluarga, dan kondisi ekonomi.

Kesejahteraan subjektif merupakan evaluasi multidimensi individu terhadap kehidupan dan pengalaman riil yang memberikan 
dampak positif, negatif, kepuasan hidup, dan kebahagiaan serta merupakan persepsi yang dirasakan oleh masyarakat sendiri tentang aspek kesejahteraan (Diener 1984; Iskandar 2007; Suandi 2007; Mc Givilray \& Clarke 2006 dalam Conceição \& Bandura 2008; Kusumo \& Simanjuntak 2009).

Hasil penelitian menunjukkan hampir separuh (46,7\%) keluarga di wilayah perdesaan dan hampir seperempat $(23,3 \%)$ keluarga di wilayah perkotaan memiliki kesejahteraan subjektif rendah. Keluarga di wilayah perkotaan memiliki tingkat kepuasan yang lebih tinggi dibandingkan keluarga di wilayah perdesaan. Sebagian besar $(86,7 \%)$ keluarga di wilayah perkotaan tidak puas dengan tabungan yang dimiliki dan separuh (50\%) keluarga di perdesaan tidak puas dengan aset atau harta lainnya yang dimiliki.

Tabel 2.

Sebaran keluarga berdasarkan pernyataan kesejahteraan subjektif

\begin{tabular}{lcccc}
\hline \multirow{2}{*}{ Kesejahteraan subjektif } & \multicolumn{2}{c}{$\operatorname{Desa}(\boldsymbol{\%})$} & \multicolumn{2}{c}{ Kota (\%) } \\
\cline { 2 - 5 } & $\mathbf{0}$ & $\mathbf{1}$ & $\mathbf{0}$ & $\mathbf{1}$ \\
\hline Makanan yang dikonsumsi & 13,0 & 86,7 & 10,0 & 90,0 \\
Kondisi rumah yang ditempati & 20,0 & 80,0 & 23,3 & 76,7 \\
Pakaian yang dimiliki dan digunakan & 10,0 & 90,0 & 16,7 & 83,3 \\
Pelayanan kesehatan & 30,0 & 70,0 & 6,7 & 93,3 \\
Pendidikan anak & 23,3 & 76,7 & 10,0 & 90,0 \\
Tabungan yang dimiliki & 23,3 & 76,6 & 86,7 & 13,3 \\
Aset atau harta lainnya yang dimiliki & 50,0 & 50,0 & 40,0 & 60,0 \\
Hubungan dengan keluarga besar & 0 & 100,0 & 3,3 & 96,7 \\
Hubungan dengan tetangga/sekitar & 0 & 100,0 & 0 & 100 \\
Lingkungan fisik tempat tinggal & 30,0 & 70,0 & 16,7 & 83,3 \\
\hline \multicolumn{2}{c}{ Keterangan: $0=$ sangat tidak puas, tidak puas, } \\
& \multicolumn{4}{c}{ 1= cukup puas, puas, sangat puas }
\end{tabular}




\section{Perbedaan Tekanan Sosial, Tekanan Psikologis, dan Kesejahteraan Subjektif di Wilayah Perdesaan dan Perkotaan}

Hasil uji beda independent sample t-test menunjukkan tekanan sosial, tekanan psikologis, dan kesejahteraan subjektif kesejahteraan subjektif lebih tinggi di wilayah perkotaan.

\section{Tabel 3.}

\section{Hasil uji beda tekanan sosial, tekanan psikologis, dan kesejahteraan subjektif}

\begin{tabular}{rcccc}
\hline \multirow{2}{*}{ Variabel } & Sig. & \multicolumn{2}{c}{ Mean } & \multirow{2}{*}{ Mean Difference } \\
\cline { 3 - 4 } & $(2$-tailed) & Desa & Kota & \\
\hline Tekanan sosial & 0,000 & 0,43 & 1,33 & $-0,900$ \\
Tekanan psikologis & 0,000 & 1,00 & 3,20 & $-2,200$ \\
Kesejahteraan subjektif & 0,040 & 23,83 & 25,83 & $-2,000$ \\
\hline
\end{tabular}

Tekanan psikologis yang dialami oleh keluarga dapat terjadi karena keluarga merupakan bagian dari sistem sosial yang lebih luas (Bronfenbrenner 1979; Berns 1985; Klein \& White 1996 dalam Miller et al. 2003). Hasil penelitian menunjukkan bahwa tekanan psikologis ternyata lebih tinggi di wilayah perkotaan. Perbedaan wilayah yakni perdesaan dan perkotaan berpengaruh positif terhadap tekanan sosial dan tekanan psikologis. Hal ini dikarenakan wilayah perkotaan memiliki karakteristik berupa perbedaan kultur sosial dan keadaan masyarakatnya (Halim 2008; Sorokin \& Zimmerman dalam Sjafari 2010), kepadatan penduduk (Berns 1985; Calhoun \& Acocella 1990; Halim 2008), dan banyak terjadinya perubahan kehidupan sehingga meningkatkan tekanan (Berns 1985; Miller et al. 2003).

Masalah terkait tekanan psikologis yang paling banyak dihadapi oleh keluarga berupa hal-hal yang mengkhawatirkan. Kekhawatiran utama yang diungkapkan berkaitan dengan anak, keluarga, dan kondisi ekonomi. Semakin jauh fase yang dihadapi oleh keluarga, maka semakin sedikit tekanan yang dirasakan karena keluarga semakin banyak belajar melakukan penyesuaian dengan kehidupan keluarga (Duvall 1971). Selain itu, semakin tua usia istri, seiring perjalanan hidupnya, akan semakin banyak hal-hal yang dialami dirasakan sebagai tekanan dalam kehidupannya (Hurlock 1980). Hal 
ini berkaitan dengan pertanyaan dalam penelitian ini, mengenai halhal yang dikhawatirkan, ditakutkan, ketidakpastian, dan kehilangan yang membuat sedih.

Kesejahteraan subjektif dipengaruhi oleh faktor internal dan eksternal (Sunarti 2009). Jika dikaitkan dengan hasil penelitian ini, ternyata kesejahteraan subjektif lebih tinggi di wilayah perkotaan. Padahal, tekanan psikologis juga lebih banyak dihadapi keluarga di wilayah perkotaan. Meskipun banyak tekanan yang dihadapi, keluarga tetap merasa puas dengan keadaan kehidupannya sekarang. Selain karena bersifat subjektif, temuan ini berkaitan pula dengan nilai-nilai yang melandasi kehidupan keluarga, sehingga tekanan yang dirasakan dapat dimaknai sebagai bagian dari kehidupan yang diterima dengan keikhlasan. Sesuai dengan teori struktural-fungsional keluarga bahwa penerimaan atau rasa puas terhadap tekanan yang dihadapi merupakan suatu bentuk kompensasi dari rasa ketidakpuasan yang dialami yang bertujuan untuk mempertahankan keseimbangan kehidupan keluarga (Sunarti 2009; Puspitawati 2009). Dapat dilihat pula dari kuesioner yang digunakan untuk mengukur kesejahteraan subjektif. Pernyataan untuk puas dan tidak puas lebih kepada akses yang banyak terdapat di perkotaan, yaitu makanan yang dikonsumsi, pakaian yang dimiliki dan digunakan, pelayanan kesehatan, pendidikan anak, sehingga ada kecenderungan kepuasan yang lebih tinggi pada keluarga di wilayah perkotaan. Sesuai dengan penelitian Suandi (2007) bahwa keluarga yang memiliki akses terbatas akan suatu sumberdaya dapat menyebabkan kepuasannya rendah. Akses berkaitan dengan kemudahan transportasi, harga, terbatasnya sumber daya yang dapat dimanfaatkan, keragaman pangan yang dapat dikonsumsi, sarana penerangan, air minum, pendidikan, akses ke pelayanan kesehatan, dan lain sebagainya. Oleh karena itu, kesejahteraan subjektif keluarga di perdesaan dimungkinkan menjadi lebih rendah dibandingkan keluarga di perkotaan dalam penelitian ini.

\section{Simpulan dan Saran}

Hasil penelitian ini menunjukkan bahwa keluarga di perkotaan lebih banyak mengalami tekanan tekanan psikologis. Dari keempat jenis tekanan psikologis yang diteliti, yang paling banyak dialami oleh keluarga adalah berkaitan dengan hal-hal yang mengkhawatirkan terutama berkaitan dengan kondisi anak, keluarga, dan ekonomi. Hasil lainnya menunjukkan bahwa kesejahteraan 
subjektif di perkotaan lebih tinggi daripada di perdesaan. Adapun beberapa faktor yang diduga mendukung hasil ini adalah nilai-nilai yang dianut oleh keluarga dan akses terhadap sumber daya.

\section{Referensi}

Baxter, L., Justin, M., Rust, L. 1951. Sharing Family Living. USA: J.B. Lippincott Company.

Berns, R. 1985. Child, Family, School, Community: Socialization and Support. London Sidney Tokyo: Hartcourt Brace College Publishers.

Bronfenbrenner, U. 1979. The Ecology of Human Development. USA: Harvard University Press.

Calhoun, JF., Acocella, JR. 1990. Psychology of Adjustment and Human Relationships $3^{\text {rd }}$ Edition. USA: Mc Graw-Hill, Inc.

Conceição, P., Bandura, R. 2008. Measuring subjective wellbeing: a summary review of the literature. New York: United Nations Development Programme (UNDP). Tersedia pada: http://www.undp.org/developmentstudies/docs/subjective_wel lbeing_conceicao_bandura.pdf [2 Juli 2012]

Diener, Ed. 1984. Subjective Well-Being. Psychological Bulletin, 95(3): 542-575.

Duvall, EM. 1971. Family Development $4^{\text {th }}$ Edition. Philadelphia, New York, Toronto: J.B. Lippincott Company.

Halim, DK. 2008. Psikologi Lingkungan Perkotaan. Jakarta: Bumi Aksara.

Hurlock, E. 1980. A Life-Span Approach, Fifth Edition. USA: McGraw-Hill, Inc.

Iskandar, A. 2007. Analisis Praktek Manajemen Sumberdaya Keluarga dan Dampaknya terhadap Kesejahteraan Keluarga di Kabupaten dan Kota Bogor. Media Gizi dan Keluarga 31(1): $1-12$. 
Kusumo, RAB, Simanjuntak M. 2009. Tingkat Kepuasan Keluarga Berpendapatan Rendah terhadap Sumberdaya yang Dimiliki. Jurnal Ilmu Keluarga dan Konsumen, 2(2): 122-136.

Lazarus, RS. 1993. From Psychological Stress to The Emotion: A History of Changing Outlooks. Annual Review of Psychology, 44: 1-21. Tersedia pada: http://www.annualreviews.org/aronline/

Mc Cubbin, H. 1988. Family Stress, Coping, and Health Project. USA: Burgess International Group, Inc.

Miller., et al. 2003. The Encyclopedia of Human Ecology. USA: ABC. CLIO, Inc.

Puspitawati, H. 2009. Pengaruh Nilai Ekonomi Pekerjaan Ibu Rumah Tangga terhadap Kesejahteraan Keluarga Subyektif. Jurnal Ilmu Keluarga dan Konsumen, 2(1):11-20.

Reiss, IL. 1980. Family Sistem in America, 3rd edition. US: Holt, Rinehart and Winston, Inc.

Sjafari, A. 2010. Keberdayaan Keluarga Miskin di Perkotaan dalam Meningkatkan Kesejahteraannya [tesis]. Bogor: Sekolah Pascasarjana IPB.

Suandi. 2007. Modal Sosial dan Kesejahteraan Ekonomi Keluarga di Daerah Perdesaan Provinsi Jambi [disertasi]. Bogor: Sekolah Pascasarjana IPB.

Sunarti, E. 2001. Studi Ketahanan Keluarga dan Ukurannya: Telaah Kasus Pengaruhnya Terhadap Kualitas Kehamilan [disertasi]. Bogor: Sekolah Pascasarjana IPB.

, Syarief, H., Hardinsyah, Megawangi, R., Saefuddin, A., Husaini. 2003. Pengaruh Ketahanan Keluarga terhadap Kualitas Kehamilan. Media Gizi dan Keluarga 27, (1): 12-22.

2009. Indikator Keluarga Sejahtera: Sejarah Pengembangan, Evaluasi, dan Keberlanjutannya. Naskah Akademik. Departemen Ilmu Keluarga dan Konsumen, Fakultas Ekologi Manusia.

Sumarno, H., Murdiyanto, Hadianto, A. 2009. Indikator Kerentanan Keluarga Petani dan Nelayan untuk Pengurangan Resiko Bencana di Sektor Pertanian. Bogor: Pusat Studi Bencana LPPM IPB. 
. 2011. Kependudukan dan Keluarga Sejahtera. Jakarta: BKKBN.

. 2012. Laporan Pelaksanaan Kegiatan Hibah Kompetensi Tahun 2012. Keragaan Ketahanan Keluarga Indonesia: Pembangkitan Teori (Middle Range Theory) dan Rumusan Kebijakan Ketahanan Keluarga Indonesia. Bogor: Departemen IKK dan DIKTI. 